\title{
SZTUKA CIERPIENIA - SZTUKA UMIERANIA. SYTUACJE GRANICZNE JAKO SZANSA „PRZEKROCZENIA PROGU NADZIEI”
}

\section{Przyczynek do zrozumienia pojęć}

Wielu autorów, którzy starają się wyjaśnić pojęcie żałoby, tworzy różne definicje tego fenomenu. Grecki psycholog, psychoterapeuta i jednocześnie osoba towarzysząca ludziom w stanach żałoby/smutku, Yorgos Canacakis, zadaje pytanie: „Co to jest smutek, co to jest żałoba?” i dochodzi do następującego wniosku: „Zasadniczo, reakcja smutku jest umiejętnością, która rodzi się z nami. Zaraz po urodzeniu jawi się ona jako znane zachowanie noworodka: płacz, krzyk, protest, narzekanie itp. Pierwszym bolesnym rozdzieleniem jest utrata rajskiego pobytu w łonie matki, a ostatnim, być może najtrudniejszym, jest oddzielenie od świata i człowieka, w momencie śmierci”. ${ }^{1}$

Ponadto Canacakis pojmuje żałobę jako „spontaniczną, naturalną, normalną i naturalną odpowiedź naszego organizmu, całej naszej osoby, na poniesioną stratę". ${ }^{2}$ „Żałoba zawsze znajdzie swój wyraz, nawet jeśli próbujemy ją powstrzymać. Wówczas przybiera postać milczenia, jako obraz fałszywy, a prawdziwy smutek pozostaje w organizmie i wpływa destrukcyjnie w sposób bezwiedny na podświadomość". 3

Z kolei Verena Kast, psychoterapeutka, wykładowca w Instytucie C.G. Junga w Zurychu, przewodnicząca Międzynarodowego

J. C a n a c a k i s, Ich begleite dich durch deine Trauer, Stuttgart 1990, s. 23.

2 Te n ż e, Trauern, Klagen, Leben können; Ich sehe deine Tränen, Stuttgart 1987, s. 28.

3 Tamże, s. 24. 
Towarzystwa Psychologii Głębi i autorka wielu książek, opisuje, że w zasadzie pojmujemy siebie, opierając się na naszych relacjach z bliźnimi, a ścisłe związki są ważnym aspektem naszej jaźni oraz dalszego życia. Śmierć ukochanej osoby wstrząsa naszym rozumieniem siebie i świata, a także zmusza nas do przemiany. Żałoba jest „emocją”, która wyraża zarówno stratę, jak również pomaga nam przepracować trudności z nią związane. ${ }^{4}$

Z kolei sławny pisarz i profesor literatury angielskiej w Oxfordzie i Cambridge, Clive S. Lewis, pisze w związku z tym tematem następująco: „Jesteśmy ogarnięci uczuciem smutku, gdy utraciliśmy człowieka lub materialne dobro, które było szczególnie cenne dla naszego życia. Z uczuciem żałoby związane są uczucia smutku, strachu, złości, poczucia winy...."

Doktor August Höglinger towarzyszy ludziom od wielu lat w procesie „utraty”. Opierając się na doświadczeniach, twierdzi: „Gdy ktoś kogoś traci, ten popada w smutek. Żałoba jest częścią procesu pozostawiania. Smutek jest takim wyrazem uczucia, który ból spowodowany utratą uwalnia wewnętrznie i na zewnątrz w sposób namacalny: to boli". ${ }^{6}$

Wspólne dla wszystkich definicji jest uznanie, że proces żałoby jest reakcją na cierpienie i na poniesioną stratę, oraz emocją, która pomaga nam zaakceptować i przepracować rozstania. Takie rozumienie tych fenomenów wydaje się specyficznym rysem kultury europejskiej w związku z tą tematyką.

4 Por. V. K a s t, Phasen und Chancen des psychischen Prozesses, Stuttgart 1982, s. 7.

5 C.S. L e w i s, Über die Trauer, Frankfurt am Main i Leipzig 1999, s. 9.

${ }^{6}$ A. Hö g 1 i n g e r, Loslassen ohne zu Vergessen, Linz 2003, s. 15; zob. także W. Mü 11 e r, Jak wyjść z depresji? Kraków 2011. 


\section{Radzenie sobie ze śmiercią w innych kulturach}

„Nie możemy uniknąć śmierci. Ona stoi na końcu naszego życia, przynajmniej na tym świecie". 7 Każda kultura, a także każda religia, ma własny sposób obchodzenia się ze śmiercią, ale także wyobrażenie o transcendencji. Wszyscy cierpimy z powodu straty kogoś/czegoś, ale bezsprzecznie w różnym natężeniu. Według relacji naukowców, którzy badali reakcje na utratę osoby ludzkiej w różnych kulturach, wszędzie po stracie pojawia się wysiłek mający na celu odzyskanie ukochanej osoby i/lub wierzy się w spotkanie po śmierci. ${ }^{8}$

W ujęciu doktryny chrześcijańskiej śmierć została pokonana przez śmierć Jezusa Chrystusa na krzyżu oraz Jego zmartwychwstanie. Także wyznanie wiary zawiera tę prawdę: „Wierzę w ciała zmartwychwstanie i żywot wieczny". "Właśnie w zmartwychwstaniu zawarta jest chrześcijańska wizja śmierci, która daje możliwość pokonania i przepracowania strachu przed nią. ${ }^{10}$ Oferowane bowiem jest życie po śmierci, jego dalsze trwanie.

W zwyczajach żałobnych kultur pozaeuropejskich znajduje się na pierwszym planie sztucznie generowane i przesadzone opłakiwanie żałobne. Człowiek płacze publicznie w sposób prawie teatralny, a ślady łez powinny być wyraźnie widoczne. ${ }^{11}$ Wiele kultur zabrania żałobnikom jedzenia, co w rezultacie prowadzi do stanu wyczerpania energetycznego, z którym wiąże się zakaz pracy. Żałobnik nie nawiązuje żadnych relacji z innymi i często przez wiele dni i tygodni trwa w odosobnieniu. Żałobnicy zaniedbują swój wygląd, rozmazują na swoim ciele popiół, nie noszą kolorowych ubrań, rozrywają często swoje odzienie, wyrywają sobie włosy i zadają rany. Po zakończonym

7 D. W o $1 \mathrm{f}$, Einen gelieb ten Menschen verlieren. Vom schmerzlichen Umgang mit Trauer, Mannheim 2004, s. 12.

8 Por. tamíe.

9 Por. Katechizm Kościoła Katoliciego, § 988-991.

10 Por. I. R a g u ž, Przeżyć śmierć jako dar. Wiara chrzescijańska w śmierć, Communio 3/2012, s. 76-78.

11 Por. D. W o lf, Einen gelieb ten Menschen verlieren. Vom schmerzlichen Umgang mit Trauer, s. 16-17. 
okresie żałoby wśród ludów pozaeuropejskich następuje obmycie brudu żałobnego oraz krwi z zadanych sobie ran, obcięcie paznokci, a brudna woda po kąpieli jest wylana na grób zmarłego jako dowód żałoby.

Ludy Wschodu, a także społeczności z obszaru śródziemnomorskiego, pozwalają żałobnikom na wyrażanie swoich uczuć w sposób wyraźny i publiczny, a nawet właściwie zmuszają do wyłącznej i demonstracyjnej - w sposób widzialny i sprawdzalny przez społeczność - troski o proces żałoby. Wszystkie te obrzędy mają pomóc żałobnikom w wyrażeniu żalu w sposób społecznie akceptowalny. ${ }^{12}$

\section{Śmierć i umieranie w dzisiejszym społeczeństwie}

Do początku XX w. śmierć człowieka zmieniała również świat otaczającej społeczności. Umieranie i śmierć łączyły ludzi. Ludzie umierali w większości w domu. W domu byli także przygotowywani do pogrzebu. Krewni razem modlili się i razem był przeżywany smutek, a także razem był przepracowywany. ${ }^{13}$

Ze zmianą form życia zmienił się także stosunek człowieka do śmierci. Tematyka śmierci i umierania jest w dzisiejszym społeczeństwie w dużej mierze wykluczona z życia społecznego. Robi się wszystko, by nie mieć nic do czynienia z tą problematyką - wyzwala ona w nas bowiem lęk. Jednak każdy z nas zostaje w pewnym momencie swojego życia skonfrontowany twarzą w twarz ze śmiercią bliskiego krewnego lub przyjaciela. Można powiedzieć, że nosi ona na sobie cechy demokratyczne - nikt nie może jej uniknąć.

Obecnie w naszym społeczeństwie śmierć człowieka jest oddelegowana do sfery publicznej. Zatrudniamy instytucje pogrzebowe, które załatwiają wszystkie wymagane formalności. Nekrologi są drukowane i wysyłane. Zmarły jest pochowany, a w święta odwiedzamy cmentarz, by go uczcić. Nowa moda wymaga, by ukryte zostało

12 Por. tamże.

13 Por. W. F u c h s, Todesbilder in der modernen Gesellschaft, Frankfurt 1973, s. 72; zob. także P. A r i è s, Geschichte des Todes, München 1980. 
to, co wcześniej umieszczano na świeczniku, niekiedy w sposób zafałszowany, mianowicie: własne cierpienie. Krewni zmarłych są zmuszeni do udawania obojętności. ${ }^{14}$

\section{Fazy umierania}

„Nadzieja, to nie tyle przekonanie, że coś się dobrze skończy, ile pewność, że coś ma sens, bez względu na to, jak się skończy". ${ }^{15}$

Jednym z kamieni milowych na drodze do bardziej humanitarnego traktowania ludzi umierających oraz osób przeżywających żałobę jest bez wątpienia ukazanie się w 1969 r. w Stanach Zjednoczonych książki On Death and Dying. ${ }^{16}$ Jej autorka, Elisabeth Kübler-Ross (*7 VIII $1926-† 24$ VIII 2004), mieszkająca w USA Szwajcarka, była psychiatrą i badaczką zjawiska śmierci. Ta publikacja była z jednej strony tak istotna, ponieważ w prawie prowokacyjny sposób pokazała szerokiej publiczności, że z umierającymi można rozmawiać, że można i należy traktować ich poważnie oraz że śmierć jest ważnym etapem życia. Książka okazała się złamaniem tabu - i tym samym przyczyniła się do wprowadzenia tego skrywanego tematu - śmierci do dyskursu publicznego. ${ }^{17}$

14 Por. tamże, s. 15.

15 V. H a v e 1, Zaoczne przestuchanie. Rozmowy z Karelem Hvizdala, Warszawa 2014, s. 220.

16 W Niemczech wydana w 1971 r., E. K ü b l e r-R o s s, Interviews mit Sterbenden, Stuttgart 1971; w Polsce ukazała się po raz pierwszy dziesieć lat poźniej: t a ż, Rozmowy o śmierci i umieraniu, Warszawa 1979.

17 Po niewyjaśnionych podpaleniach jej Centrum w Kalifornii i w Wirginii Elisabeth Kübler-Ross przenosi się w 1995 r. do Scottsdale w Arizonie, gdzie mieszka jej syn. Oboje opiekują się Emanuelem Rossem, rozwiedzionym mężem i ojcem, aż do jego śmierci. Po serii ataków w latach 90. Elisabeth Kübler-Ross pozostaje częściowo sparaliżowana. Dopiero po 78 latach, 24 V 2004 r., dochodzi w jej życiu do ,przejścia/przełomu”, jak określa to wydarzenie. Przy łożu jej śmierci bawią się wnuki. Nieco wcześniej dotknęła w wywiadzie telewizyjnym istotnej zasady jej życia: „W Szwajcarii byłam wychowywana zgodnie z zasadą: praca, praca, praca. Jesteś wówczas wartościowym człowiekiem, jeśli pracujesz. To jest fundamentalny 
Z drugiej strony, Elisabeth Kübler-Ross zwróciła tą książką uwagę na normy prawne, które nie zostały jeszcze dotąd w taki sposób opisane, a opiekunom dała nieco poczucia pewności w kontaktach z przerażającymi, często niezrozumiałymi sposobami zachowania osób nieuleczalnie chorych. Szczególnie pielęgniarkom, ale także lekarzom i innym pomagającym dodała tym samym odwagi w docieraniu do osób nieuleczalnie chorych i wyzwalania ich dzięki temu ze swoistej izolacji. ${ }^{18}$

Czytając, obecnie przełomową, książkę Elisabeth Kübler-Ross, można ze zdumieniem zauważyć, że nadal znajdują się w niej sprawy ważne i godne odkrycia. Z drugiej strony, niektóre ówczesne przemyślenia wydają się współcześnie - na szczęście - oczywistością. W rzeczywistości „fazy umierania” nie są jakimś „egzotycznym” zjawiskiem, które odnosi się wyłącznie do umierającego. Po raz pierwszy opisane przez Kübler-Ross fazy możemy także odnaleźć w życiu codziennym - choć w łagodniejszych formach - u nas samych lub u naszych bliskich: nawet w sytuacji stosunkowo trywialnej straty, jak utrata portfela lub kluczy domowych, doświadczamy w zwięzłej formie ,fazy umierania". ${ }^{19}$ Ale nawet przy okazji wielkich strat w naszym życiu, takich jak utrata bliskich przez śmierć lub separację, utrata pracy itp., przeżywamy je jako „etapy żałoby”. Dlatego nie jest zaskakujące, gdy do opisu procesu żałoby sięga się (często nawet w sposób ukryty) po model tych faz. Znajomość

fałsz. W połowie pracować, w połowie tańczyć. To jest właściwa proporcja! Sama za mało tańczyłam i za mało bawiłam się“.

18 Zjawiskiem na stałe wpisującym się w dziedzictwo chrześcijaństwa było zakładanie tzw. hospicjów - miejsc troski o chorych, biednych, rannych, umierających, pielgrzymujących. To fundamenty dzisiejszych szpitali. Były one nie tylko dziełem sporadycznym, ale stanowiły stały element założeń klasztornych (wpisanych nawet w regułę zakonną - zob. benedyktyni). Obecnie jakby o tym zapominamy. Szerzej na ten temat zob. Z. G a j d a, Do historii medycyny wprowadzenie, Kraków 2011, s. $186-203$.

19 Podobnym zagadnieniem zajmowali się także: V. K a s t, Phasen und Chancen des psychischen Prozesses; D. W olf, Einen gelieb ten Menschen verlieren. Vom schmerzlichen Umgang mit Trauer. 
zatem tych etapów może nam pomóc w zrozumieniu siebie i innych w życiowych kryzysach. ${ }^{20}$

E. Kübler-Ross opisała pięć etapów emocjonalno-duchowego rozwoju pacjentów ciężko chorych: pierwsza faza: zaprzeczenie i izolacja; druga faza: złość; trzecia faza: targowanie się; czwarta faza: depresja; piąta faza: pogodzenie się.

Nie należy jednak tego rozumieć tak, że poważnie chorzy ludzie przechodzą przez te fazy w sposób „łatwy”, jedna po drugiej, rozpoczynając zaprzeczeniem i izolacją, by w końcu dojść do pogodzenia się. Kübler-Ross zawsze podkreślała, że chociaż nakreślona została jedna z możliwych dróg, to jednak zna ona wiele odchyleń. ${ }^{21}$ Długość i czas trwania poszczególnych faz różnią się w zależności od osoby - przede wszystkim jednak różnią się kolejnością, w której są przeżywane. Jeśli człowiek dotarł do etapu „pogodzenia się”, ponownie może nieco później dojść do głębokiej depresji, negocjacji, gniewu czy też powtórnego zakłamania. Czasami nawet różne fazy istnieją równolegle. Poniżej zostaną one dokładniej przedstawione.

Pierwsza faza: z a pr z e c ze n i e i i zolac ja. Większość pacjentów reagowała na rozpoznanie u nich choroby nowotworowej: „Nie, to nie u mnie”. Prawie wszyscy próbowali zaprzeczać zachorowaniu. Wielu z nich miało także nadzieję na cud. ${ }^{22}$

Gdy otrzymujemy fatalną wiadomość, jesteśmy przede wszystkim w „szoku”: stajemy się jakby umarli - zamieramy z wrażenia. „To nie może być”. „Przecież nie ze mną”. Bronimy się przed czymś strasznym i nie chcemy tego uznać za prawdziwe. Człowiek chory, który

20 Szczegółowe opracowanie faz umierania zob. E. Kübler-Ros s, D. K e s s 1 e r, Dem Leben neu vertrauen. Den Sinn des Trauerns durch fünf Stadien des Verlusts finden, Stuttgart 2006.

${ }^{21}$ Por. E. K ü b l e r- R o s s, Rozmowy o śmierci i umieraniu, Poznań 2002, s. 145. Opisanych przez Szwajcarkę faz nie należy (nie wolno) traktować schematycznie. Każdy przypadek chorobowy jest inny, gdyż dotyczy innej osoby. Ważnym czynnikiem jest w tym procesie czas. Tego muszą się nauczyć bliscy osoby chorej, opiekunowie oraz personel medyczny. Szerzej zob. L. G e i s l e r, Arzt und PatientBegegnung im Gespräch, Frankfurt a. Main 1992.

22 Por. tamże, s. 55n. 
słyszy diagnozę: rak, uważa to być może za błąd. „Czuję się jeszcze w pełni zdrowy. Oni na pewno się pomylili’. Czasami poszukuje porad innych lekarzy w nadziei, z wewnętrzną prawie pewnością, że to nie może być prawda. „Nie dostrzegam niczego". Niektórzy, chorujący od niedawna, przeżywają swoje życie nadal po prostu tak, jakby nic się nie stało. Sygnalizują, każdą cząstką swej istoty: „Ta sprawa mnie nie dotyczy".

Ta obrona, którą dusza trzyma dla człowieka w gotowości, jest przydatna, by chronić nas przed emocjonalnym przeciążeniem. Odepchnięcie może być pierwszym krokiem, by w końcu - czasami po długim zmaganiu - „nie do pomyślenia” stało się możliwe. Ten etap może wystąpić wielokrotnie - zwłaszcza, gdy nowe szokujące wieści o progresji choroby lub jej nawrocie dotrą do chorego. Dla osób towarzyszących śmiertelnie chorym decydujące w tym momencie jest, by przyjąć taką postawę odrzucania prawdy i zaakceptować ją jako „normalną”. Zupełnie co innego, niż wstrząs przywołujący rzeczywistość, jest potrzebne w takim momencie: być razem z chorym, nie pozostawiać go samemu sobie i aktywnie słuchać. Niewielu jest pacjentów, którzy uparcie trwają w tej fazie aż do śmierci.

Druga faza: g n i ew. Pacjenci zastanawiają się: „Dlaczego ja?” Pytanie jest powiązane z gniewem, emocjami, złością, oburzania się na najbliższych, członków rodziny i pracowników szpitala. ${ }^{23} \mathrm{Ta}$ faza jest chyba dla osób opiekujących się umierającym najbardziej nieprzyjemna. Chory człowiek jest dla opiekunów w tym okresie po prostu nie do zniesienia! Może nawet czuć się dość komfortowo: puszcza parę w gwizdek, wykrzykuje głośno swoją złość i rozpacz. Wreszcie znalazł zawór odciążający. Może to przynieść korzyści. „Dlaczego właśnie ja?” - tak brzmi pytanie, które często jest tutaj zadawane, lub „Dlaczego Bóg jest tak niesprawiedliwy?” Ważna w tej fazie jest umiejętność rozróżniania uczuć własnych od stanów emocjonalnych osób chorych.

Trzecia faza: $t$ a r g o w a n i e s i ę. Pacjent wymusza nagradzanie za dobre zachowanie. Jego głównym pragnieniem jest prawie zawsze

${ }_{23}$ Por. tamże, s. 66-60. 
dłuższy okres życia lub nawet kilka dni bez bólu i dyskomfortu. Najczęściej dochodzi do układu handlowego z Bogiem, co utrzymywane jest w tajemnicy przed opiekunami i bliskimi. ${ }^{24}$ E. Kübler-Ross opisuje tę fazę jako najczęściej dość niestabilną. Osoby towarzyszące śmiertelnie chorym mają wrażenie, że chory pogodził się już ze swoim losem. Towarzyszą temu często postawy spokoju, zrelaksowania, większej aktywności i otwartości. „Wiem, że muszę umrzeć - ale chciałbym jeszcze przeżyć chrzest mojego wnuka". Chory negocjuje „z Bogiem i ze światem”. Czasami formułowane jest to wewnętrznie, niekiedy głośno. Gdy ten cel zostanie osiągnięty, pojawiają się nieuchronnie jeszcze bardziej atrakcyjne cele i etapy, które chora osoba chce osiągnąć. Oczywiście, śmiertelnie chory człowiek nie jest w tym zakresie lepszy od całej reszty: złożone przyrzeczenia są szybko zapominane. Korekta lub ocena takiej postawy nie ma w tym okresie najmniejszej zasadności. Ten odcinek drogi trzeba przejść razem $\mathrm{z}$ umierającym.

Czwarta faza: de pres j a. Śmiertelnie chory nie jest w stanie już dłużej zaprzeczać swojej chorobie; jest coraz słabszy i bardziej nieszczęśliwy. ${ }^{25} \mathrm{Na}$ tym etapie ważne jest znalezienie drogi dojścia do wnętrza chorego. E. Kübler-Ross rozróżnia dwa aspekty fazy depresji. Po pierwsze, depresja jako reakcja na postrzegane straty: utrata integralności cielesnej, utrata możliwości osobistych i zawodowych, ale również utrata czegoś, co nie da się zrealizować, swego rodzaju porażki w czasach dobrej formy zdrowotnej. Ludzie chorzy mają często $\mathrm{w}$ tym czasie wielkie pragnienie dzielenia się swoimi przemyśleniami. Chcą wyrazić swój żal, by słuchano ich skarg. Istnieją jednak jeszcze inne korzenie depresji: depresja przygotowawcza - jak nazywa ją E. Kübler-Ross. Chodzi w tym kontekście o straty zagrażające - ostatecznie o utratę życia ziemskiego. Jest to cicha forma żałoby. Chory jest często zamknięty w sobie, mniej komunikatywny. Ten etap wymaga zupełnie innych form pomocy: głębokiej spokojnej obecności, wspólnego trwania w łzach oraz cierpliwego wsłuchiwania

24 Por. tamże, s. $95 \mathrm{n}$.

25 Por. tamże, s. 98-122. 
się w to, co w tym okresie przynosi ulgę. E. Kübler-Ross opisuje konflikty, które mogą się pojawić w tym czasie między chorymi a ich bliskimi i lekarzami. Osoba chora może przestać walczyć o życie, chociaż krewni i lekarze wciąż widzą możliwości. Ważne jest, by zdawać sobie sprawę, że teraz inne problemy są na pierwszym planie, a chorzy potrzebują tego etapu wycofywania depresyjnego na przygotowanie się do kolejnych etapów emocjonalnych.

Piąta faza: p o g o d z e n i e s i ę. Pacjent przeżywa swoje ostatnie dni wraz z własnymi mniej lub bardziej cichymi oczekiwaniami. $\mathrm{Na}$ tym etapie jest już bardzo słaby i zmęczony. Teraz przychodzi ostatni spokój przed długą podróżą. ${ }^{26}$ Depresja jest również jednym z silnych i bardzo zakaźnych uczuć, z którymi należy się zmierzyć. Człowiek chory sprawia wrażenie smutnego, narzekającego, zrezygnowanego. Czasami zamyka się w sobie, przeżywa lęki lub nadmiernie płacze. Wielu, ale w żadnym wypadku wszyscy, nieuleczalnie chorzy osiągają w pewnym momencie ten etap. Zadaniem osób towarzyszących nie jest domaganie się czegoś takiego od nich. Gdy chory osiągną1 tę fazę, rozpoczyna się „ostatni spoczynek przed długą podróżą”. Zmaganie się skończyło. Człowiek chory przyznał, że życie zbliża się do końca. Prawie „obojętny emocjonalnie”, spokojny stan został osiągnięty. Pragnienie, by zobaczyć jeszcze odwiedzających, często wygasa. Spojrzenie jest skierowane w innym kierunku, wewnętrznie. Chory prawie nie podejmuje rozmów. Od towarzyszących umierającemu wymagane jest jedynie to, by jako milczący uczestnicy tego stadium bez lęku mogli uznać, że teraz cisza jest najbardziej znaczącą formą komunikacji. Na szczególną uwagę w tej fazie zasługują bliscy umierającego. Oni bowiem powinni zrozumieć, że takie „wycofanie się" śmiertelnie chorego nie oznacza, że zostali odrzuceni, ale że on jest teraz bardzo ze sobą i chce odejść. Oni zaś powinni - mimo bólu - pozwolić umierającemu odejść. ${ }^{27}$

26 Por. tamże, s. 123-146.

27 Analizując dorobek oraz działania E. Kübler-Ross, można jednoznacznie stwierdzić, że wniosła ona na zupełnie inną płaszczyznę rolę osób towarzyszących choremu. Wskazała na nową jakość opieki, pokazując, jak wielki wpływ ma ona 


\section{Nadzieja}

We wszystkich fazach obecna jest prawie zawsze - czasem mimo wszystko - nadzieja. Wbrew wszelkiemu rozsądkowi człowiek chory ma nadzieję na wyzdrowienie, na cud. Dla ekspertów medycznych jest to czasem trudne do zniesienia. Ich zadaniem w tym momencie nie jest umacnianie chorego $\mathrm{w}$ jego nadziei, lecz po prostu zgoda na jego nadzieję. Często nadzieja ta skierowana jest wyłącznie na złagodzenie dolegliwości - lub - ostatecznie nadzieja na to, co przychodzi po śmierci. ${ }^{28} \mathrm{~W}$ każdym razie nadzieja nigdy nie jest jednoznaczna. Właśnie tę wieloznaczność powinno się umieć zaakceptować. Pojawia się bowiem tutaj wielka szansa na przemianę nadziei. Od nadziei na to, że coś jeszcze może się potoczyć dobrze, aż do nadziei (duchowej), że coś ma sens.

Eschatologia nie traktuje o nadziei, która marzy o czymś bliżej nieokreślonym, ale wzmacnia roszczenie, by była ona uzasadniona. ${ }^{29}$ Powodem tej nadziei nie jest jednak zwykłe życzenie, lecz historyczne wydarzenie i związane z nim doświadczenie. Chodzi o doświadczenie czegoś całkowicie nowego, co emanuje z pracy, życia i losu Jezusa z Nazaretu. Eschatologia zatem traktuje, zarówno o doświadczeniu tego nowego, jak i o nadziei na jego ostateczne spełnienie. ${ }^{30}$

Warto w tym kontekście dokładniej określić pojęcie „nowego”. Znamy kategorię „,nowego” jako nazwy tego, co nie było wcześniej, ale zawsze było już w sferze możliwości i dlatego też podlegało prawu stawania się i przemijania. Jeśli to „nowe” byłoby pojmowane jako realizacja możliwości, to wówczas, mówiąc ontologicznie,

na proces zmagania się z cierpieniem i umieraniem. Umiejętność prowadzenia rozmów urasta w tej perspektywie do ,sztuki“; zob. E. Joh n s on Taylor, Co powiedzieć? Jak rozmawiać z chorymi o duchowości, Kraków 2008.

28 Por. M. S c hö n le b e r, Im Tod ist Leben. Die Frage nach dem Tod, Donauwörth 1994, s. 16n.

29 Zob. L. B a lt e r, Nadzieja życia wiecznego skonkretyzowana $w$ śmierci $i$ zmartwychwstaniu człowieka, Communio 4(1984)4, s. 74-94.

${ }_{30}$ Zob. A. A m a to, Nadzieja, której źródłem jest Chrystus, Communio 23(2003)5, s. 51-69. 
rzeczywistość ma prymat przed możliwością. Właśnie na tym założeniu opiera swą tezę Kohelet, mówiąc, że w zasadzie nic nowego nie ma pod słońcem (por. Koh 1,9).

Tezę tę stawiają jednak pod znakiem zapytania, zarówno nauczanie Jezusa o królestwie Bożym, jak też chrześcijańskie twierdzenie o wskrzeszeniu Go z martwych. Całą eschatologię chrześcijańską można skoncentrować w osobie Wypowiadającego słowo Chrystusa w Janowej Księdze Objawienia: „Oto czynię wszystko nowe” (Ap 21, 5). To nowe, które tu się dzieje, to nic innego niż odnowienie ludzi oraz całego stworzenia. Jednak w tym odnowieniu nie chodzi o urzeczywistnienie immanentnych możliwości obecnych w świecie, lecz o nowe stworzenie świata. Podobnie, jak stworzenie w sensie chrześcijańskim należy rozumieć jako creatio ex nihilo, tzn. jako stworzenie „z niczego", tak również należy pojmować jego odnowienie. Jest to bowiem konsekwencja, która wynika z idei wskrzeszenia Jezusa z martwych. Nie chodzi w nim o reanimację trupa, ale o to, że Ukrzyżowany został przez Boga powołany do życia w zupełnie nowy sposób, ontologiczny i egzys tencjalny. W języku ontologii filozoficznej można zatem powiedzieć, że eschatologia chrześcijańska utrzymuje prymat możliwości nad rzeczywistością. ${ }^{31}$

\section{Interpretacje śmierci}

Dzieje ludzkości relacjonują o rozmaitych próbach podchodzenia do faktu śmierci. Były takie, które traktowały umieranie jako największy dramat człowieka, ale również takie, które odnosiły się do tej rzeczywistości w sposób trywializujący (np. teza Epikura). ${ }^{32}$ W kulturze zachodniej dominowały dwa główne poglądy, obecne w procesach myślowych aż do dnia dzisiejszego:

31 Na ten temat zob. E. J ü n g e 1, Die Welt als Möglichkeit und Wirklichkeit, Evangelische Theologie 29/1969, s. 417-442.

32 Por. V. M e s s o r i, Wyzwanie wobec śmierci, tłum. T. J a n i a, Kraków 1995, s. 27. 
- Przez śmierć nieśmiertelna dusza oddziela się od śmiertelnego ciała i żyje niezależnie dalej (dualizm ciała i ducha).

- Człowiek umiera cały (ciało i dusza). Przy końcu świata będzie sąd ostateczny, a następnie zmartwychwstanie i nieśmiertelność ( ten pogląd ma swoje korzenie w biblijnym upadku człowieka, względnie w nauczaniu apokaliptycznym).

W naturze człowieka obecny jest znamienny paradoks, który łączy się z jego bytową przemijalnością i brakiem moralnej harmonii. Mimo jednak takiego stanu rzeczy wydarzenie śmierci, wpisane na stałe w ludzką egzys tencję, nie jest dla człowieka jedynie mrocznym i beznadziejnym końcem życia. Zjawisko to przybiera raczej formę niezgłębionego misterium. W ujęciu filozoficznym ów tajemniczy wymiar ma swe korzenie w ontologicznej relacji człowieka do Absolutu, do „źródła” życia. W perspektywie religijnej to tajemnicze „przejście” do świata umarłych rozumiane jest jako zmaganie/mocowanie się ze śmiercią z nadzieją na jej ostateczne pokonanie. Zasadność misterium mortis tkwi bowiem wyłącznie w relacji do nieśmiertelnego, wiekuistego Boga - Pana życia i śmierci. Chrześcijaństwo, oparte na biblijnym objawieniu, prezentuje w tym kontekście jedynego, wiecznie żyjącego Boga, którego w pełni objawia Jezus Chrystus. To On jest źródłem nadziei i sprawcą z martwych powstania. Dawcą życia nieśmiertelnego. Śmierć zatem w takim ujęciu symbolizuje proces przejścia ze świata doczesnego do królestwa wieczności i łaski. ${ }^{33}$

\section{Odpowiedź wiary chrześcijańskiej}

Na pytanie, co to jest śmierć i co po niej następuje, chrześcijaństwo odpowiada w świetle Biblii. Istnieje wiele rozproszonych wypowiedzi w Biblii na temat śmierci, zmartwychwstania i życia wiecznego. Są

33 Por. P. M r z y g ł ó d, Filozoficzne rozumienie śmierci oraz jej interpretacja w świetle antropologii św. Tomasza z Akwinu, Perspectiva 18(2011)1, s. 142-143. Warto w tym kontekście wspomnieć, że w niektórych religiach Dalekiego Wschodu (buddyzm, religie hinduistyczne) śmierć, jako stadium przejściowe, prowadzi do innej formy egzystencji, np. przez wędrówkę dusz. 
one jednak różnie komentowane i różnie interpretowane, dlatego też znajdujemy różnice w poglądach na temat śmierci i życia wiecznego wśród różnych wyznań. Wszystkie jednak wyznania chrześcijańskie łączą poniższe stwierdzenia.

Śmierć jest nieuniknionym i nieodwracalnym końcem życia ziemskiego. Powrót ludzi na ziemię w sensie wędrówki dusz i reinkarnacji według rozumienia chrześcijańsko-biblijnego nie istnieje. Człowiek i jego ziemskie życie są niepowtarzalni. ${ }^{34}$

Według wiary chrześcijańskiej śmierć nie jest końcem życia, ale początkiem nowej egzys tencji. Pogląd ten opiera się na słowach Jezusa i Jego zmartwychwstaniu. Już od początków Kościoła nowina o życiu po śmierci należy do elementarnego depozytu wiary chrześcijańskiej. ${ }^{35}$

Egzys tencja człowieka po śmierci zależy od tego, czy w trakcie swojego życia otwierał się on na miłość Boga i przekazywał ją innym ludziom, czy nie. Decyzję w sprawie ostatecznego losu człowieka wyobrażali sobie często chrześcijanie jako „specjalny sąd”, podczas którego Bóg jako sędzia wypowiada wyrok względem ludzi. To zdarzenie może być również rozumiane jako proces duchowy. Człowiek uzyskuje w śmierci jasne poznanie Boga i siebie, bez możliwości dalszego samooszukiwania siebie. W kontekście tej nowego rodzaju przejrzystości sama śmierć jest już sądem!

Jeśli ktoś radykalnie i ostatecznie odrzucił w życiu miłość Boga i zawiódł bliźnich, także po śmierci pozostanie w otchłani. Właśnie takie oddzielenie od Boga i Jego miłości ma na myśli Nowy Testament, gdy mówi o „piekle” lub ,potępieniu”. Życie człowieka zagrożone jest realną możliwością odstępstwa, gdyż może on swobodnie dysponować sobą i odrzucić Boga. Do takiej możliwości człowieka odnosi się Jezus, gdy przestrzega przed konsekwencjami umyślnego i dobrowolnego zamykania się w sobie (brak miłości).

\footnotetext{
34 Por. tamże, s. 142-143.

35 Zob. H.U. vo n B a 1 th a s a r, Tajemnica śmierci, Communio 8(1988)6, s. 35-38.
} 
Wszystkie konkretne prezentacje piekła są tylko próbą uczynienia czegoś uchwytnego zmysłami, co przekracza zdolności umysłowe i wyobraźnię człowieka. Piekło nie jest miejscem, które wciąż płonie w ogniu, a ludzie nie są tam torturowani lub smażeni. Przeciwnie, jest to stan, w którym człowiek nie ma żadnego związku z Bogiem i Jego miłością. Taki stan człowieka, samotność, do której słowo „miłość” nie może przeniknąć, to jest piekło. ${ }^{36}$

Kto podążał w życiu za swoim sumieniem, kto nie zawiódł wezwania Boga oraz bliźnich, ten wchodzi do życia wiecznego, tj. nieograniczonego żadnym czasem. Ten stan opisuje Nowy Testament, gdy mówi o „niebie” lub o „wprowadzeniu do chwały Bożej”:

„Panie, Ty dla nas byłeś ucieczką

$\mathrm{z}$ pokolenia na pokolenie.

Zanim góry narodziły się w bólach, nim ziemia i świat powstały,

od wieku po wiek Ty jesteś Bogiem.

Miarą naszych lat jest lat siedemdziesiąt

lub, gdy jesteśmy mocni, osiemdziesiąt;

a większość z nich to trud i marność:

bo szybko mijają, my zaś odlatujemy.

Naucz nas liczyć dni nasze, abyśmy osiągnęli mądrość serca”. (Ps 90, 1-2. 10. 12)

Ostatnie słowo

„Myśmy łupina tylko i listowie.

A wielka śmierć, którą ma każdy w sobie, to jest ów owoc, o który zabiega wszelki byt". ${ }^{37}$

(Rainer Maria Rilke)

36 Por. J. R a t z i n g e r, Wprowadzenie w chrześcijaństwo, Kraków 2006, s. 313-314.

37 R.M. R i 1 k e, Każdemu daj śmierć jego własna, w: tenże, Poezje, tłum. M. J a s tr u n, Kraków 1993. 
Śmierć dotyka nas wszystkich, czy tego chcemy, czy też nie. Wszyscy możemy się stać w dowolnym czasie osieroconymi i żałobnikami, którzy są zależni od pomocy innych. Ciągle mamy do czynienia z ludźmi, którzy się smucą, muszą zgodzić się na rozłąkę i potrzebują naszego wsparcia. Żałoba/smutek, podobnie jak rozłąka i umiejętność pozostawienia, jest częścią codziennego życia i każdy człowiek musi kiedyś przejść ten etap. Nie ma uniwersalnego scenariusza przebiegu żałoby, żadnej „recepty na smutek”, chociaż fazy umierania przebiegają u wszystkich ludzi w mniej lub bardziej podobny sposób.

\section{Przepracowanie lęku}

Możemy przypuszczać, że u wszystkich tych, którzy opowiadają się za uśmiercaniem ludzi w stanie wegetatywnym, pod pewnymi warunkami, jest - lęk. Lęk zrozumiały. Strach, który powstaje z zewnętrznego punktu widzenia: patrzą na człowieka chorego w stanie śpiączki i widzą jakby pozbawione wszelkich funkcji ciało, które wydaje się wyłączone ze społeczności żywych. To musi wywoływać lęk. Któż miałby odwagę wyobrazić sobie taki stan u siebie? Ale lęk jest matką ślepców, mówi porzekadło ludowe, rozumiejąc to dosadnie: strach ogłupia. ${ }^{38}$

Tego rodzaju głupotą nie wolno dzisiaj obciążać innych. W ciągu bowiem ostatnich stu lat wiele nauczyliśmy się jako ludzkość, poznając świat osób niepełnosprawnych, a mianowicie: „spojrzenia od wewnątrz". Potrafimy, o ile to tylko możliwe, rozpoznawać perspektywę osób chorych lub niepełnosprawnych. Dowiedzieliśmy się, że osoba niepełnosprawna inaczej (często ostrzej) postrzega świat, niż przypuszczamy. Wiemy, że jej chęć życia i pragnienie nie zależą od rodzaju niepełnosprawności, lecz od warunków, które są jej oferowane przez otoczenie. Kiedy postrzegamy potrzeby pacjenta w postawie

38 Ważną i wartościową publikacją dla osób towarzyszących umierającym jest: J.-C. S t u d e n t (red.), Sterben, Tod und Trauer-Handbuch für Begleitende, Freiburg $2006^{2}$. 
empatii, szanujemy jego godność i zapewniamy satysfakcję z życia. Zmienia się bowiem optyka: to nie postrzeganie zewnętrzne stanowi punkt odniesienia, ale ważne jest zrozumienie, co się dzieje w takiej osobie w środku, jak ona ocenia swoją sytuację. I nagle otrzymujemy zupełnie inny obraz! ${ }^{39}$

Co trzeba zrobić, by przezwyciężyć strach i chronić nas - jako osoby towarzyszące ludziom w sytuacjach granicznych - przed ślepotą i głupotą? Oczywiście, że pomaga nam wiedza, pomaga praktyka. Ale uczuć nie da się „wyłączyć” przez głowę. Lęki najczęściej są nierozsądne. W związku z tym wiedza pomaga tylko w sposób ograniczony. Wiedza może jednak stanowić zachętę oraz dodać odwagi do przyglądania się uczuciom bardziej dokładnie i krytycznie. W kontaktach z ludźmi w ekstremalnych sytuacjach życiowych, jak np. trwały stan wegetatywny, ale także demencja lub zespół zamknięcia, musimy nauczyć się jednego - opanowywania własnego lęku. Ponadto należy poznać dokładnie własne lęki i obawy, i mierzyć się z nimi - ciągle. W tym procesie konieczna jest także fachowa pomoc. Wówczas stopniowo dochodzi do procesu przemiany. Nie oznacza to pozbycia się lęków i obaw, ale będą one znane i nie będą mimowolnie dominować w zachowaniu. Panowanie nad lękami oznacza zatem bycie wolnym w służebnym działaniu. ${ }^{40}$

$* * *$

Podsumowując, należy postawić sobie pytanie o jądro wszystkich koncepcji paliatywnych: troskliwe obchodzenie się z innymi ludźmi wymaga przede wszystkim troskliwości wobec siebie tych, którzy opiekują się ciężko chorymi. Taka troskliwość nie oznacza ochrony przed rygorami życia. Nie oznacza ona również zahartowania. Oznacza natomiast to, by być otwartym i wrażliwym na potrzeby

39 Por. T. K 1 i e, J.-C. S t u d e n t, Wege aus dem Dilemma der Sterbehilfe, Freiburg 2011, s. 22n.

40 Katechizm rozwija w tym kontekście motyw Chrystusa lekarza, KKK § 1503. 
innych oraz by wyczuwać powstające w takich sytuacjach obawy i mierzyć się z nimi. ${ }^{41}$ Oznacza ona jednocześnie, by do tego zadania przygotować się w taki sposób, który mobilizuje siły wewnętrzne, wzmacnia wytrzymałość. Pomocna opieka wobec ludzi znajdujących się w ekstremalnych sytuacjach życiowych stawia wysokie wymagania. Chodzi o to, by sprostać tym wymaganiom w tym sensie, w jakim sformułowała to Elisabeth Kübler-Ross, mówiąc: „Gdybyśmy chronili kaniony przed wichurami, nie moglibyśmy odkryć ich piękna".

ks. Dariusz PATER

${ }^{41}$ Por. T. K 1 i e, J.-C. S t u d e n t, Wege aus dem Dilemma der Sterbehilfe, s. $126 n$. 